\title{
Socio-spatial violence prevention: Inhibiting violence in Caracas, Venezuela through spatial planning
}

\author{
Prevenção socioespacial da violência: \\ Inibindo a violência em Caracas através do planejamento espacial
}

Nicholas Kasang

MSc in Urban and Regional Planning at University of Applied Sciences Frankfurt am Main (FH FFM), researcher at Global Urban Studies Institute (GLOBUS), Berlin, BE - Germany, e-mail: nicholas.kasang@gmail.com

\begin{abstract}
Contemporary urban growth in many cities in Latin American and Africa has been accompanied by unprecedented levels of urban violence. Latin America epitomizes this trend as three of the world's most dangerous cities, Ciudad Juárez, San Pedro Sula, and Caracas, are located within this region (JÁCOME; GRATIUS, 2011, p. 2). Of these three, Caracas is notable because its exorbitant homicide rate cannot be explicitly attributed to the illicit drug trade-cartel wars that consume Mexico, nor is it represented by the civil conflict-gang violence that afflicts Central America. Moreover, the Venezuelan context is further distinguished as inequality, which is consistently cited as the primary catalyst for the emergence of everyday reactionary violence, is not overtly characteristic of the contemporary situation. Rather, caraqueño insecurity has largely been attributed to the exacerbation of social factors that perpetuate violence as "[...] an end in itself or a [mechanism] to injure/ eliminate another person in order to resolve an interpersonal conflict [...]" (SANJUÁN, 2002, p. 95). Based on this reality, this work proposes the inclusion of socio-spatial interventions into contemporary prevention initiatives. Spatial interventions have shown a "[...] significant capacity to prevent the occurrence of violence in areas that are either totally or partially excluded from economic development and larger society [...]" (DÍAZ; MELLER, 2012, p. 23). Implications of this work have the capacity to augment predominantly technical violence prevention precedent and enhance knowledge on alternative mechanisms to prevent insecurity. This study employs a comprehensive literature review in conjunction with data analyses in the development of a spatial proposal for Caracas.
\end{abstract}

Keywords: Urban violence prevention. Socio-spatial intervention. Latin American urban development.

\section{Resumo}

O crescimento urbano contemporâneo em muitas cidades da América Latina e da África tem sido acompanhado por níveis sem precedentes de violência urbana. No entanto, a América Latina resume mais essa tendência: três das cidades mais perigosas do mundo são localizadas na região: Ciudad Juárez, San Pedro Sula e Caracas (JÁCOME; GRATIUS, 2011, p. 2). Dessas três, Caracas é particular. Sua taxa exorbitante de homicídios não pode ser atribuída às guerras dos cartéis de drogas ilícitas que consomem o México, nem é representativa da violência 
de gangues que aflige a América Central. Além disso, o contexto venezuelano é distinto, porque a desigualdade, constantemente citada como o principal catalisador para o surgimento de violência reacionária não é característica em aprofundamento da situação contemporânea. A insegurança caraquenha, pelo contrário, tem sido amplamente atribuída à exacerbação de determinados fatores sociais, perpetuando a violência como "[...] um fim em si mesmo ou um [mecanismo] para ferir/eliminar outra pessoa, a fim de resolver um conflito interpessoal [...]" (SANJUÁN, 2002, p. 95). Por conta dessa realidade, este trabalho propõe a inclusão de intervenções socioespaciais em iniciativas de prevenção contemporâneos. Intervenções espaciais têm mostrado uma "[...] significativa capacidade de prevenir a ocorrência de violência nas áreas que são total ou parcialmente excluídas do desenvolvimento econômico e da sociedade em geral [...]" (DÍAZ; MELLER, 2012, p. 23). Implicações deste trabalho podem levar ao desenvolvimento de precedente de prevenção da violência predominantemente técnico e assim melhorar o conhecimento sobre os mecanismos alternativos para evitar a insegurança. Este estudo emprega uma ampla revisão da literatura em conjunto com análises de dados para o desenvolvimento de uma proposta espacial para Caracas.

Palavras-chave: Prevenção da violência urbana. Intervenção socioespacial. Desenvolvimento urbano da América Latina.

\section{Introduction}

In 2011, the World Development Report calculated that $25 \%$ of the world's population lives with levels of violence that have "trans-generational repercussions" (ADAMS, 2012, p. 1). This violence has shifted from the notions of civil war and conflict to contemporarily focus more on criminal activity, terrorism, and civil unrest. Consequently, the spatial distribution of violence has deviated from the locations of historic transgressions, with violence increasingly experienced in the expanding cities of Latin America and Africa.

Latin America is notable in this context as nearly $80 \%$ of the region's population resides in urban areas that are considered the world's most dangerous (SALIEZ et al., 2012). In particular, three cities epitomize this reality: Ciudad Juárez, Mexico; San Pedro Sula, Honduras; and Caracas, Venezuela. These cities are considered three of the most dangerous on the planet due to their exorbitant homicide rates. Yet among these three, the Venezuelan capital is particularly notable since local violence cannot be predominantly attributed to the illicit drug tradecartel wars that consume Mexico, nor is it due to the civil conflict-gang violence that has largely characterized Central America since the 1990s. Venezuela, in comparison, boasts a gross domestic product per capita that is higher than the regional average due to oil deposits, which are estimated to be the fifth-largest known reserves in the world (SALIEZ et al., 2012, p. 41). Furthermore, over the last two decades, the capital has experienced marked reductions in poverty and urban inequality, the latter of which is consistently cited as the primary catalyst for the emergence of everyday reactionary violence (FAJNZYLBER; LEDERMAN; LOAYZA, 2002; VANDERSCHUEREN, 1996). Nevertheless, homicides in the capital metropolis have increased by $506 \%$ since 1990 (SANJUÁN, 2002, p. 94) and recently reached 130 homicides per 100,000 inhabitants, more than double the rate for the remainder of the country (GRATIUS; VALENÇA, 2011, p. 11).

To address the increasing phenomenon of contemporary violence, the following multi-level study is organized to expose the urban factors that have increased the propensity for violent and criminal actions in Caracas. This examination is facilitated by a conceptual grounding in the theory of violence and its forms. The incidence of violence in cities and the larger relationship between urban processes and insecurity is subsequently addressed, before the experience of urbanization in Venezuela is appraised to determine its influence on the contemporary exacerbation of caraqueño insecurity. A secondary analysis of political, economic, and social phenomena is likewise included, as violence occurs in a milieu of societal development that is similarly determinant.

Following this preliminary study, a set of hypothetical socio-spatial interventions is proposed to 
address the complexity of violence in the urban typology in which it concentrates: informal communities of the Venezuelan capital. These proposals focus specifically on spatial intervention, which has shown a

[...] significant capacity to prevent the occurrence of violence in extensive areas of Latin America that are either totally or partially excluded from economic development and larger society [...] (DÍAZ; MELLER, 2012, p. 23).

Moreover, spatial intervention provides a mechanism to "[...] weave together socio-cultural development aspects, economic aspects, as well as operation and maintenance solutions [...]" and thus facilitate the comprehensive functionality necessary to prevent urban insecurity (KRAUSE, 2011, p. 108).

Motivation for this work stems from the recently enacted Gran Mision A Toda Vida Venezuela por una Convivencia Segura, a contemporary Venezuelan initiative for public safety on the national level. The central objective of the Gran Mision is to "[...] transform structural, situational, and institutional factors that generate violence and crime [...]" without requiring "[...] more police, more jails, or greater penalization [...]" (GOBIERNO BOLIVARIANO DE VENEZUELA, 2012). However, as recent protests have demonstrated, the programs of the Gran Mision have had little effect repressing the occurrence of violence in Caracas. Therefore, this work attempts to contribute to the development of comprehensive security planning for the caraqueño communities most affected by violence while simultaneously encouraging the incorporation of spatial attributes within prevention programming for similar situations of urban insecurity.

\section{Violence: Categories and instigators}

To sufficiently understand the contemporary situation of Caracas, it is necessary to first conceptualize the theory of violence, particularly in relation to cities. The World Health Organization (WHO) defines violence as

[...] the intentional use of physical force or power, threatened or actual, against oneself, another person, or a group, that either results in or has a high likelihood of resulting in injury or death [...] (KRUG; DAHLBERG; MERCY, 2002, p. 4).

In addition to these tangible outcomes, the WHO also includes the less-obvious consequences of violent behavior, "such as psychological harm, deprivation, and mal-development that compromise the wellbeing of individuals, families, and communities [...]" (KRUG; DAHLBERG; MERCY, 2002, p. 4). This complexity within the definition alludes to the multiple attributes and influences of the concept and has led social scientists to further distinguish between the various forms of violence. In its most encompassing classification, violence is differentiated into direct, structural, and cultural forms, with direct violence composing the most common understandings of the term : direct violence is the direct infliction of physical or psychological harm on another individual resulting in intentional fatalities, assault, and/or sexual harassment (MUGGAH, 2012, p. 19).

The occurrence of direct violence generates uncertainty, which is expressed as fear and insecurity, thus promoting the notion that particular institutions or cultural establishments require protection (MOSER, 2004, p. 4). To generate such protection, mechanisms are constructed to negate this threat. Yet, intrinsic to many of these mechanisms are structural or institutional attributes that exclude or restrict certain portions of a population from achieving a just and equitable lifestyle. In response to this reality, the concept of structural violence was introduced by Galtung (1969) to address the issue of "[...] how various institutions and organizations cause harm to others as a normal consequence of the way they are structured and operate [...]" (SANTA-BARBARA, 2007, p. 234). The injustices (real or perceived) derived from structural violence may, in turn, “[...] provoke direct violence as a response to exclusion from social, political, or economic systems [...]" (MARC; WILLMAN, 2010, p. 11). Moreover, these forms of structural and direct violence can be exacerbated by cultural violence, which is the "[...] justification of direct and structural forms through nationalism, racism, sexism, and other types of discrimination and prejudice [...]" (FISCHER, 2007, p. 188). 
A secondary classification of violence evaluates the motivation behind violent actions. These motivations fall into three broad characterizations, social, economic, and political, which can degrade into further forms of violence when conflict arises from the incompatible or contradictory goals of individuals or groups. Moser and McIlwaine (2004) contextualize the intentionality in these forms:

- Social violence: violence motivated by the will to achieve or maintain social power and control;

- Economic violence: violence motivated by material gain, which can take the form of street crime, drug-related violence, or kidnapping;

- And Political violence: violence inspired by the will to win or hold political power (FISCHER, 2007, p. 60).

The final form, political violence, can have a range of violent outcomes, such as "[...] the normalization of violence, [deriving] a system of norms, values, or attitudes which allow, or even stimulate, the use of violence [...]", and can culminate in a form of state violence perpetrated through a lack of reform within the police and judiciary systems or the inability to provide legitimate institutional control over violence (AGOSTINI et al., 2010, p. 3). The violence in Venezuela specifically reflects this distinction, as even President Chávez has justified the violent appropriation of private property as an action against social injustice (JÁCOME; GRATIUS, 2011).

Due to the multifaceted and interrelated nature of violence, the need to comprehensively evaluate the phenomenon by examining factors that influence behavior or aspects that increase the risk of committing or becoming a victim of violence became obvious to many scholars early in the development of conceptual theory. The Social Disorganization Theory predicted that many risks for violence were aggravated by the socio-spatial characteristics of the cities themselves. This idea was advanced through the Ecological Systems Theory, which sought to demonstrate that no single cause determined or explained violence; rather, multiple types of nested-factors, with bi-directional influences in and between each other at different levels, combined to contribute to violence in an overlapping and continuous manner (Figure 1) (KRUG; DAHLBERG; MERCY, 2002).

In line with the Ecological Systems Theory, urban violence has been described as following a similar, concomitant pattern:

[...] rapid growth of cities feeds the chaotic formation of [marginal areas], in which overcrowding and competition for scarce resources combine with weak state security presence to foster criminality and violence [...] (MARC; WILLMAN, 2010, p. 15).

The urban growth rate has been directly attributed to enhanced violence (compared with city size or population density) as rapid urban growth contributes to infrastructure deficiencies that exacerbate the everyday pressures of earning a living and raising a family, increasing tensions within families and communities and making it easier for everyday conflicts to escalate into violence (MARC; WILLMAN, 2010). Poor spatial allotments can further amplify the propensity for conflict, creating "[...] situational opportunities for perpetrators to commit crimes without being seen or pursued by neighbors or police [...]" (MARC; WILLMAN, 2010, p. 66). Similarly, limited service provisions in one

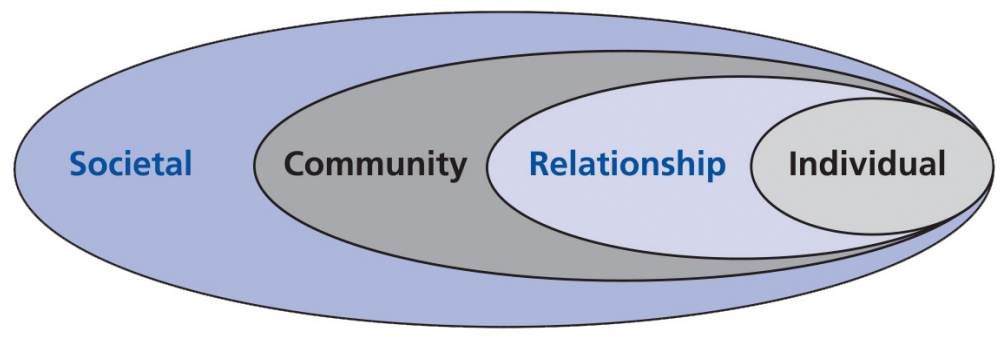

Figure 1 - The nested factors of the Ecological Systems Theory

Source: KRUG; DAHLBERG; MERCY, 2002. 
community as opposed to another exacerbate a sense of social exclusion, which is itself a driver of violence, that then has the power to convert areas of a city into "no-go zones" for non-residents and law enforcement professionals (MARC; WILLMAN, 2010 , p. 26). In this way, the real and perceived threats of violence combine to generate what Agbola (1997) has termed an

[...] architecture of fear": "increasingly higher walls and barriers, more elaborate security systems, the presence of private security, and, often, a stronger police presence in wealthier areas [...] (AGBOLA,1997, p. 26).

Such architecture fragments public space, breaks down social cohesion, perpetuates widespread insecurity, and, ultimately, diminishes the overall quality of urban life.

\section{Venezuelan urbanization and the propensity for violence}

The contemporary exacerbation of urban insecurity in Caracas can be significantly attributed to processes of spatial organization that have occurred since the early $20^{\text {th }}$ century. By the beginning of the 1930s, oil and the state had come to dominate the economy and processes of urban expansion in Caracas (BRICEÑO-LEÓN, 2007). Programs such as the Plan Rotival, which sought to order urban expansion through a system of straight boulevards and diagonal avenues, epitomized this trend, as government policy reserved the city center for commercial and office use and pushed the metropolis into its modern linear shape, which made urban transportation necessary for city life (STANN, 1975). The purchase of large single tracts of land in the city's east and their simultaneous subdivision and development into housing at a relatively narrow

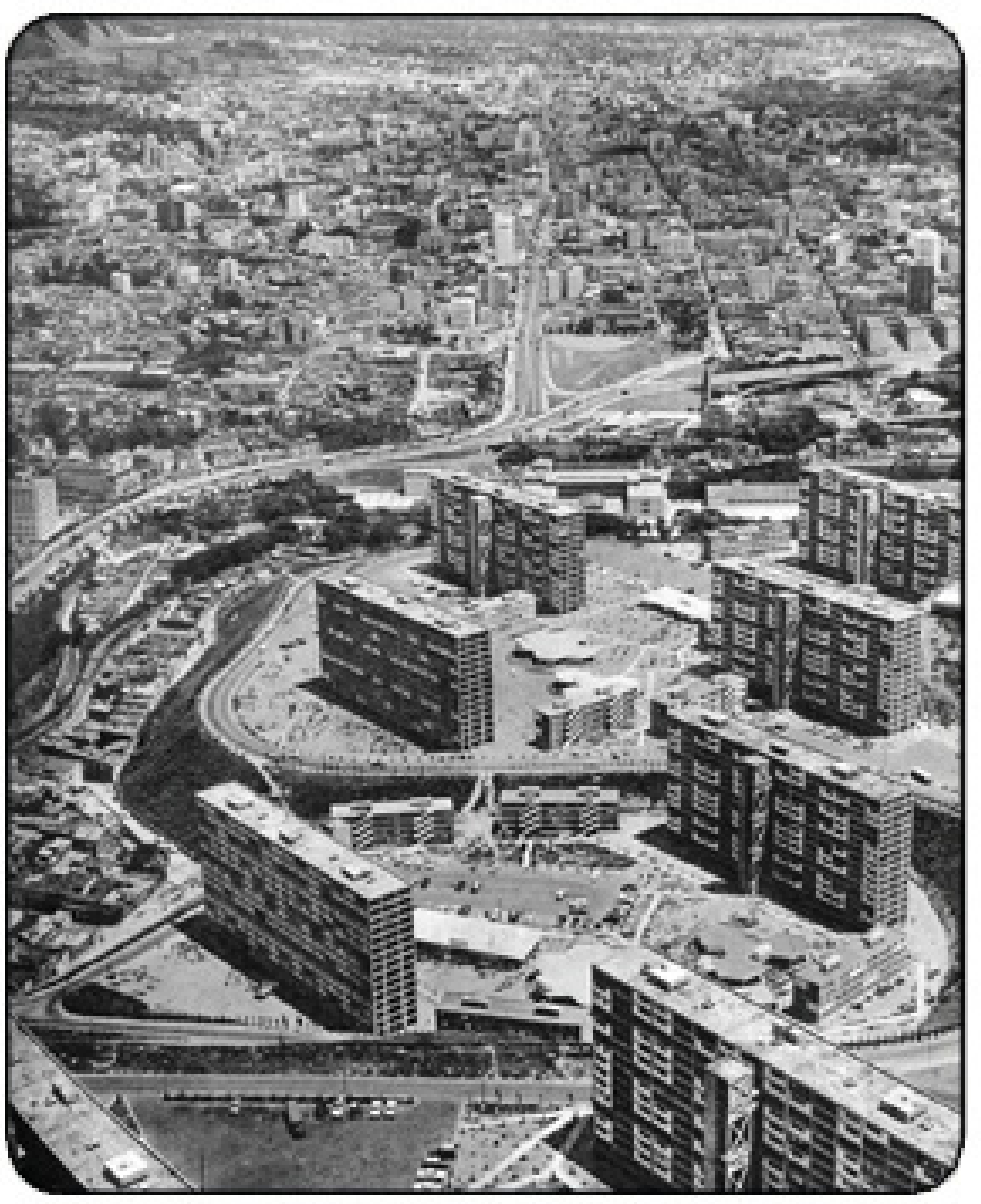

Figure 2 - The Super Bloque of January 23 shortly after construction Source: CENTENARIO DE VILLANUEVA, 2011. 
price range reinforced the segregation initiated by such early planning endeavors (STANN, 1975, p. 160). Thus, "[...] the west became home to the worker, while the wealthy and near-wealthy went east [...]" (STANN, 1975, p. 159).

During the 1950s, federal control of urbanization continued as oil productivity doubled and the gross national product increased by 95\% (RAY, 1969, p. 5). Consequent rural-urban migration and informal urbanization were strongly controlled as the regime sought to address low-income populations through a series of Corbuserian-influenced urban renewal projects, which were built to accommodate 180,000 low-income residents across the capital and neighboring municipalities (Figure 2) (KÜHN, 2013, p. 195). However, the Revolution of January in 1958 ushered in a new and entirely unprecedented phase of informal development. Restrictions on land settlement were lifted, and families immediately poured out of crowded informal developments to claim vacant land on the outskirts of the city.

When families, still in the countryside, heard about the new opportunities, the flow of migration sped up tremendously, thus increasing further demand for new development [in Caracas] (RAY, 1969, p. 32).

Such was the rate of growth that an official report estimated that 100 new dwellings were being erected in informal settlements daily (RAY, 1969). Not surprisingly, most of these settlements, locally known as barrios, "[...] trace their origin back to those first twenty-four months following the revolution than any other period" in caraqueño history (RAY, 1969, p. 6).

In response to the explosive growth experienced in Caracas in the late 1950s, the Central Office of Coordination and Planning (CORDIPLAN) was created to "[...] propose the general framework for physical and spatial planning on a national scale [...]" (FRIEDMANN, 1965, p. 17). Over the ensuing decade, CORDIPLAN encouraged the growth of alternative urban poles across the country. However, the Middle Eastern oil embargo of the early 1970s intensified the patterns of territorial occupation in Caracas as laborers from neighboring countries flocked to the Venezuelan capital, locating predominantly in the barrios (BRICEÑO-LEÓN, 2007). Yet after a few years of substantial growth, a shift in the dynamics of oil wealth and a presidential decree forbidding the establishment of new factories in Caracas altered incomes (SÁNCHEZ, 2013), which had allowed families to improve their dwellings within five years in the 1960s (BRICEÑO-LEÓN, 2007). Subsequently,

[...] a process of generalized urban deterioration set in, where congestion and decline, [caused] by the decreasing availability of urban plots, [saw] families resort to building 2, 3, or even 7 stories on to already precarious dwellings [...] (BRICEÑOLEÓN, 2007, p. 99).

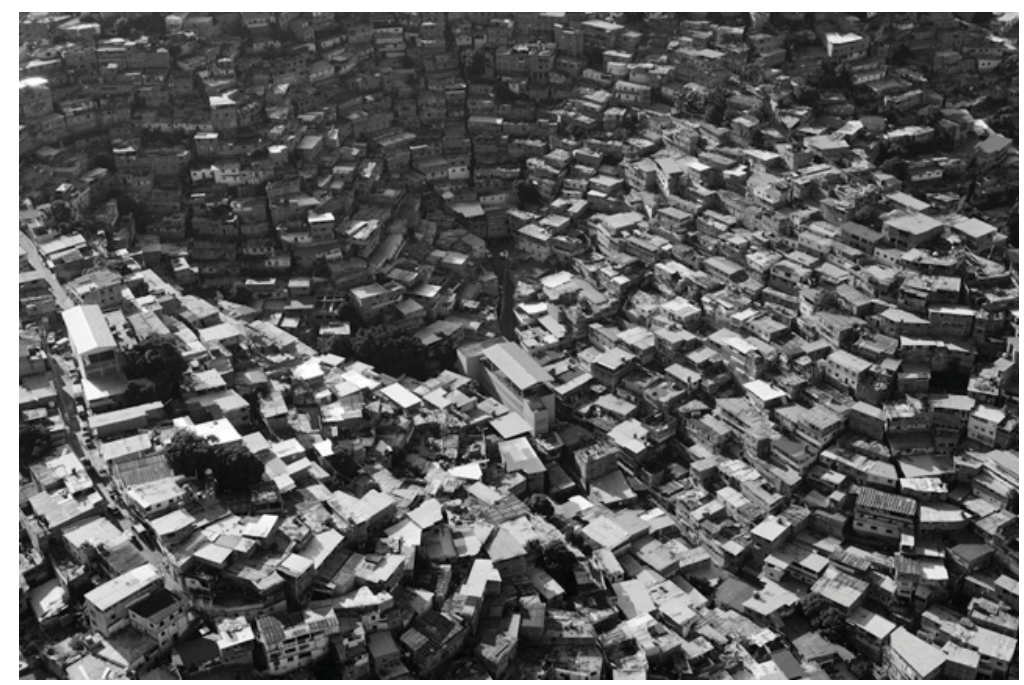

Figure 3 - The extreme congestion of the barrios Source: BRILLEMBOURG; KLUMPNER; SCHWARTZ, 2011. 
Barrio density across the metropolis correspondingly grew to six times that of the "formal" city (Figure 3) (ALEMÁN, 2008). Spatially, this density encouraged violence and crime because it inhibited opportunities for natural surveillance. From an environmental psychology perspective, this density also promoted conflicts between people,

[...] both because of aggression that appears with many people and few effective norms for cohabitation but also because unplanned urban growth and subsequent densification [produced] tortuous territories that [were] easily controlled by criminal groups and refractory to efficient and secure action by the police [...] (BRICEÑO-LEÓN, 2005, p. 1640).

Due to extreme urban consolidation and the growth of insecurity, Caracas subsequently experienced a process of de-densification from the 1980s onward. Both formal and informal urban sprawl expanded the city to the east (AZZELLINI; LANZ; WILDNER, 2013). The convergence of these contradictory processes fomented the propagation of fortified enclaves: apartment high-rises, gated communities, peripheral office complexes, and shopping centers, guarded by private security and high-tech surveillance. The reproduction of these developments in the 1990s reiterated socioeconomic divisions as the growth of fortified enclaves for the elite coincided with $30 \%$ of the urban population, exclusively in the barrios, lacking municipal connection to water and sanitation systems (AZZELLINI; LANZ; WILDNER, 2013, p. 15). However, the largely positive reception of many enclaves (including by the poor, who also experienced closed shopping centers as "safe places in which to spend their leisure" (BRICEÑO-LEÓN, 2007, p. 98) created a "[...] public space fragmented and articulated in terms of rigid separations [...]" (CALDEIRA, 2000, p. 4).

The fragmentation of public space has constrained social activities and promoted the adoption of radical changes in habits, cultural routines, and collective behavior. Social mixing and interaction are deliberately avoided, public space is used only exclusively, and the traditional places of social encounter, such as parks, squares, and even streets, have either lost their function and are abandoned or are used only in transit (ALEMÁN, 2008). These voids, which exemplify structural violence, have enabled mass media - especially television - to become disproportionately more important "as a means for people who are isolated from each other to make sense of their lives" (ADAMS, 2012, p. 32).

Yet, mass media has equally been shown to exacerbate the volatility of the situation, "[...] naturalizing the violence that is reported, trivializing other types of violence, and increasing fear and insecurity among the population" (ADAMS, 2012, p. 17). Such uncertainty has perpetuated violence as it has "[...] reproduced and circulated stereotypes, stimulated scapegoating, and spurred increased segregation, negation of citizenship rights, and further aggression" (ADAMS, 2012, p. 27). With the ubiquitous presence of television in even the poorest urban homes, cultural consumption patterns have caused this information to spread massively (BRICEÑO-LEÓN; ZUBILLAGA, 2002). Therefore, the multiplication of panic, suspicion, and arbitrariness in social life have inhibited "[...] the mechanisms of informal social control and the dynamic interactions between residents and local institutions [...]" (MARC; WILLMAN, 2010, p. 232). Consequently, a vicious cycle of crime and violence has become socialized in contemporary Caracas.

\section{Supplemental instigators of violence in Venezuela}

Contemporary violence in Caracas cannot be solely attributed to spatial processes of urbanization. The homicide rate, which was comparatively low during the period of rapid urban development, exploded as urban growth began to stabilize around the turn of the millennium. Furthermore, this homicide rate was attained despite reductions in the percentage of the population experiencing poverty and inequality. Therefore, it is necessary to evaluate other phenomena that have contributed to the substantial growth of violence in the Venezuelan capital.

The following sub-sections analyze the circumstances that are supplemental to the spatial development of the modern metropolis to further contextualize violence in contemporary Caracas. According to the forms of violence outlined in 
the first section, these segments will characterize violence into political, social, and economic categories, as growth in the violence of Caracas has transpired within a milieu of political adjustment, market fluctuation, and the increasingly asymmetrical development of social relations (SANJUÁN, 1998).

\section{Political factors of violence}

Since the onset of increased urban violence in the Venezuelan capital in the 1980s, the notion that insecurity was resolved through the use of reactionary violence has become progressively more socialized. In February 1989, the government of Carlos Andres Perez epitomized this trend, deploying the military to violently end the unrest due to working-class protests. An uncompromising reaction plunged the capital into violence shortly thereafter, when military personnel took to the streets in 1992 with the objective of occupying the government. The accompanying increase in violence appeared to be the product of a severe institutional crisis that "[...] immersed Venezuela in a kind of anomie, [which] lasted until an elected president again took office in 1995 [...]" (BRICEÑOLEÓN, 2007, p. 92). Although homicide numbers stabilized at around 4,000 per year during that time, the situation changed dramatically in 1999 when Lieutenant Colonel Hugo Chávez was elected president. Beginning in that year, the number of homicides grew nationally, surpassing 13,000 in 2003 (BRICEÑO-LEÓN, 2007, p. 93).

Of particular influence in the election of Chávez was the apparent legitimization of what Holston (2007) has called "insurgent citizenship": the coalescence of insurgent movements that "[...] redefine the nature of social incorporation and the distribution of resources [...]". According to Holston, these movements often derive from the construction of informal communities on the margins of cities and society, as informal urban dwellers create a vast new city while simultaneously proposing a different order of citizenship (HOLSTON, 2007). The election of Chávez afforded this alternative citizenship a platform to challenge the entrenched formulations of order and repression. Accordingly, the political sphere became progressively more polarized, which provoked an increasingly political-cultural form of violence (Chavismo vs. Oposición) from the year 2000 onward. "The rise of political tensions led to open confrontation in significant events - the 2002 coup, the oil strike in 2004, and street confrontations between supporters and opponents of the government [...]", thus contributing to a marked overall de-institutionalization of security (ZUBILLAGA, 2013, p. 110). Subsequently, the predominant sentiment resulting from political violence became the fear "[...] of being attacked or invaded by political opponents in periods of high confrontation [...]" (ZUBILLAGA, 2013, p. 115).

\section{Social factors of violence}

As a consequence of this fear, alternative and predominantly individual means to ensure personal security have been adopted by the majority of the population. These means fall along a continuum from defensive to perverse and extreme. Defensive responses have led to the widespread privatization of security, with an estimated 700,000 private security agents - double the number of policemen in Caracas - dispersed across the city (GRATIUS; VALENÇA, 2011). More perverse responses to violence have seen the formulation of contradictory social identities, which are restricted to individual areas of the city and validate violence against anyone who is not part of the more or less homogeneous world of "us" (ZUBILLAGA, 2013, p. 106). Perhaps the most extreme response to violence has been citizens' increased approval of the right to kill: $60 \%$ support the right to kill to defend one's property, whereas killing an individual who attacks the community was condoned by $33 \%$ of respondents (BRICEÑO-LEÓN; CAMARDIEL; AVILA, 2006). These reactions are exacerbated by citizens' desire to buy firearms, which, in 2004, attained $47.8 \%$ of the population (BRICEÑO-LEÓN, 2007). Some experts have noted that most legal and illegal weapons in Venezuela - between 8 and 15 million - are in civilian hands, which, in a country of approximately 28 million inhabitants, "[...] indicates that nearly $50 \%$ of the population is armed [...]" (JÁCOME; GRATIUS, 2011, p. 3).

Not surprisingly, urban insecurity has become less instrumental (focused on a remunerative goal) and more relational, with $64 \%$ of the violence 
in Caracas derived from fights with friends or acquaintances of the most primary environment (SANJUÁN, 1998). Violence, in turn, has become "[...] an end in itself or its purpose is to injure or eliminate another person to resolve an interpersonal conflict [...]" (SANJUÁN, 2002, p. 95). As a result, every citizen becomes a potential victim, and even neighbors become potential perpetrators. Therefore, community fragmentation has been promoted as fear has become widespread across the various social spaces of the metropolis. This fear has eroded the social fabric of communities as citizens, recognizing the lower probability of being a victim of violence at their residence (Table 1), have become prone to spend more time inside their households, promoting a process of communal "unsociability" (ZUBILLAGA, 2013, p. 117).

Such withdrawal has facilitated a marked deterioration in the control of social networks and coexistence schemes, as communal reliance and trust have become unnecessary for both the individual and the group. Thus, violence has created an atmosphere in which everyday encounters with insecurity are perceived as a natural aspect of a perverse state of order, and fundamental elements of democracy, such as dialogue, negotiation of conflict, and the execution of political and civil citizenship, are no longer expected or necessary. Correspondingly, individualism and a lack of optimism have become "[...] inherent and constitutive facts of contemporary Venezuelan society that influence shared expectations and the vision of the future [...]" (SANJUÁN, 2002, p. 93). This lack of faith produces a feeling of hopelessness and often results in even more insecurity, as violence is no

Table 1 - Perceptions of the Locations of Violence in Caracas

\begin{tabular}{lc}
\hline In the Place of Residence (i.e., Home) & $1.48 \%$ \\
In Public Spaces of the Residence Area & $34.93 \%$ \\
In Public Spaces outside the Residence Area & $26.45 \%$ \\
In Private Spaces (Offices, Workplaces, Restricted Areas, etc.) & $16.25 \%$ \\
Private Vehicles \& Public Transport & $20.51 \%$ \\
No Declaration & $0.38 \%$ \\
Total & $\mathbf{1 0 0 . 0 0 \%}$ \\
\hline
\end{tabular}

Source: ELUURI et al., 2010. longer merely an aspect of survival in the city but rather a characteristic that is necessary to survive.

\section{Economic factors of violence}

The economic situation has compounded the occurrence of violence further, as the country has been plagued by price fluctuations and inflation over the last decade, which have made Caracas the most expensive city in the Americas (THE ECONOMIST INTELLIGENCE UNIT, 2013). The resultant economic violence derives from insufficient employment opportunities; the official unemployment rate in Caracas has grown since the capital reduced its participation in national industrial production in the 1980s (MAYTÍN, 2013). Consequently, informal employment has become an integral aspect of the urban economy, representing $62 \%$ of all employment across the capital (BRICEÑO-LEÓN, 2007). Although not intrinsically violent, the informal economy has migrated toward violence for economic gain, including drugs and arms trafficking and especially kidnapping, as restrictions on informal sellers have increased. Moreover, available jobs in the service sector require educational achievement, which is inaccessible to the majority of adolescents from the barrios. Thus, perverse expressions of the informal economy are increasingly accepted by excluded youth, who strive for consumption patterns that "[...] cannot be satisfied with the conventional methods of work and savings [...]" (BRICEÑO-LEÓN, 2007, p. 95).

The growth of economic violence, in turn, has affected individuals' capacity to improve their living conditions and to dissociate from perverse forms of informal employment. Violence propagates the fear of victimization and thus inhibits information flows about jobs, delays the establishment of small shops or stalls, restricts productivity by limiting the number of hours of work performed, and depresses sales because potential purchasers do not go out at night (MUGGAH, 2012). Moreover, there is the additional expense that families and companies must bear, being obliged to allocate sizeable portions of their budgets to security: approximately 1.9\% of the GDP per capita is spent on private security measures (BRICEÑO-LEÓN; ZUBILAGA, 2002). 
Additionally, it is necessary to consider the societal costs of insecurity, as deficient investment (both nationally and internationally) and the emigration of professionals and skilled workers perpetuate inferior services, such as those in the health sector (JÁCOME; GRATIUS, 2011). The populations residing in the barrios predominantly experience this burden, magnifying the discrepancies that concentrate in marginalized social strata. This concentration has largely negated the reductions of poverty and inequality achieved over the last 20 years ${ }^{1}$ and has exacerbated the occurrence of structural violence in the Venezuelan capital.

\section{Proposal for prevention in Caracas}

Due to the complex and multifaceted reality of violence in Caracas, a comparably manifold response has been required from the Venezuelan authorities. However, the Gran Mision a Toda Vida Venezuela por una Convivencia Segura, a national policy for public safety enacted in 2012, has done little to address the complexity of urban insecurity in Caracas. Preliminary stages of the initiative have predominantly focused on provisions for institutional strengthening, such as police reform and disarmament. Although they are imperative to the prevention of violence, these activities have significantly overlooked many daily experiences of insecurity, thus prolonging a form of political violence in which deficient governmental provisions for security normalize violent occurrences (AGOSTINI et al., 2010).

Consequently, the national government must advance violence prevention activities and supplement contemporary initiatives of the Gran Mision. Spatial intervention provides a significant opportunity as it has been shown to "[...] prevent the occurrence of violence in extensive areas of Latin America that are either totally or partially excluded from economic development and larger society." (DÍAZ; MELLER, 2012, p. 23). Moreover, redevelopment of the built environment affords the capacity to weave together various socio-cultural aspects, developmental aspects, and economic aspects as well as operational and maintenance solutions (KRAUSE, 2011). This ability to comprehensively address violence is integral to its prevention as activities to reduce violence, like the occurrence of violence itself, must work on multiple and bidirectional levels.

In accordance with the opportunity provided by spatial redevelopment, the following sub-sections propose hypothetical interventions for the barrios of Caracas, the urban typology in which violence concentrates. These proposals are presented to complement contemporary measures, which have been or continue to be enacted through the Gran Mision. They are proposed with a particular orientation toward the relevant actors within the Gran Mision, but they also focus on enhancing communities' capacity to address the incidence of violence themselves.

\section{Enhancing the physical presence of municipal institutions in the Barrios}

As the spatial characteristics of the barriosoften located on mountainous slopes and composed of a complex labyrinth of streets and alleyways - accentuate insufficient municipal responses to violence in these settlements (BRICEÑOLEÓN, 2007), spatial intervention should enhance the physical presence of municipal institutions in affected communities. The establishment of better security and justice institutions could substantially reduce the occurrence of direct forms of violence, since $70 \%$ of households attribute insecurity to the deficient presence of police (ELJURI et al., 2010). Moreover, attending to the overall institutional deficiencies that characterize the barrios would address the structural forms of violence inflicted on such communities and would likewise assist in reducing the expressions of cultural violence that have developed with the formulation of self-centered and divergent spatial identities.

To strengthen security and justice provisions in the barrios, precedent can be drawn from the

\footnotetext{
${ }^{1}$ Since 1990, Venezuela has experienced a marked reduction in poverty levels, with the percentage of the urban population living in poverty and extreme poverty decreasing from $49 \%$ to $28 \%$ in 2010 . Urban inequality (represented by the Gini Coefficient) has similarly dropped to 0.39 in 2010 from a level of nearly 0.50 circa 1990 (SALIEZ et al., 2012).
} 


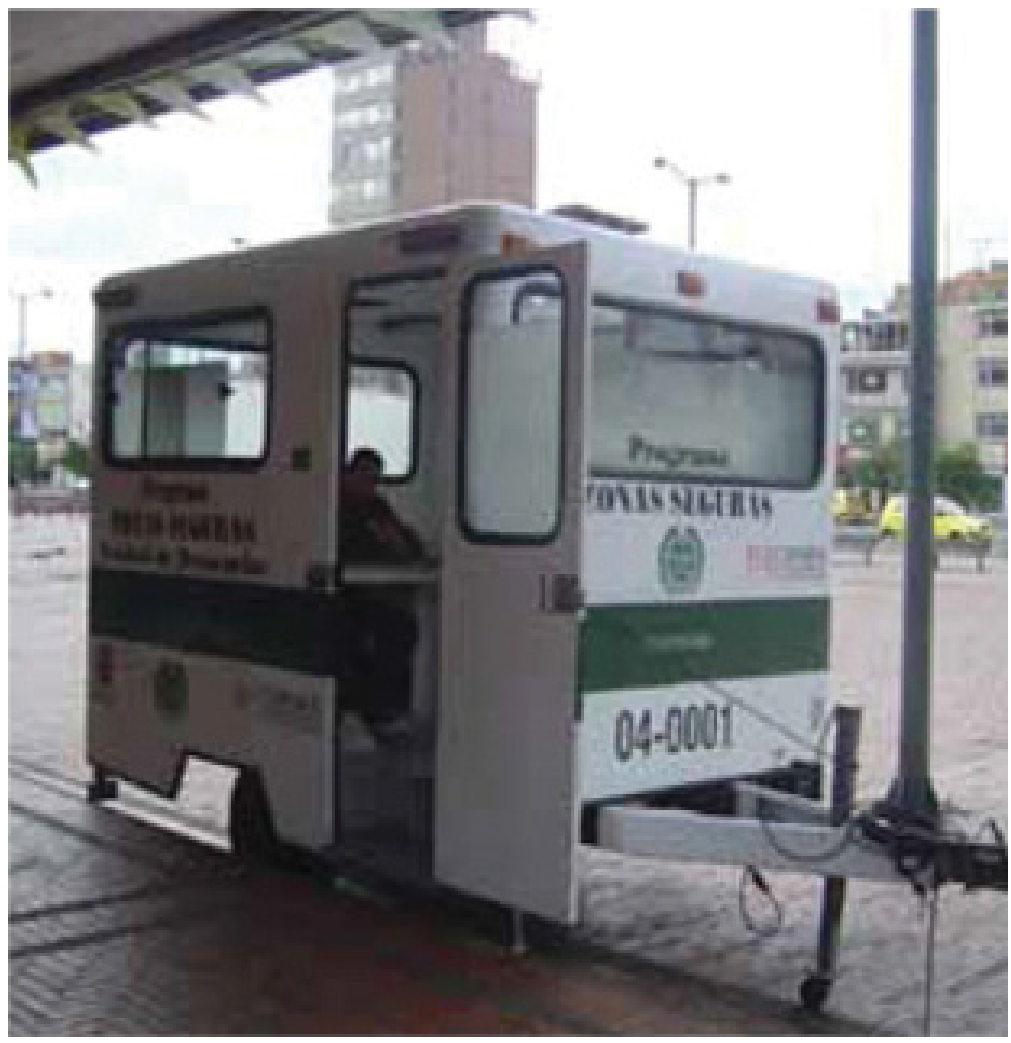

Figure 4 - Mobile police facility, Bogotá, Colombia Source: UNITED NATIONS HUMAN SETTLEMENTS PROGRAMME, 2011.

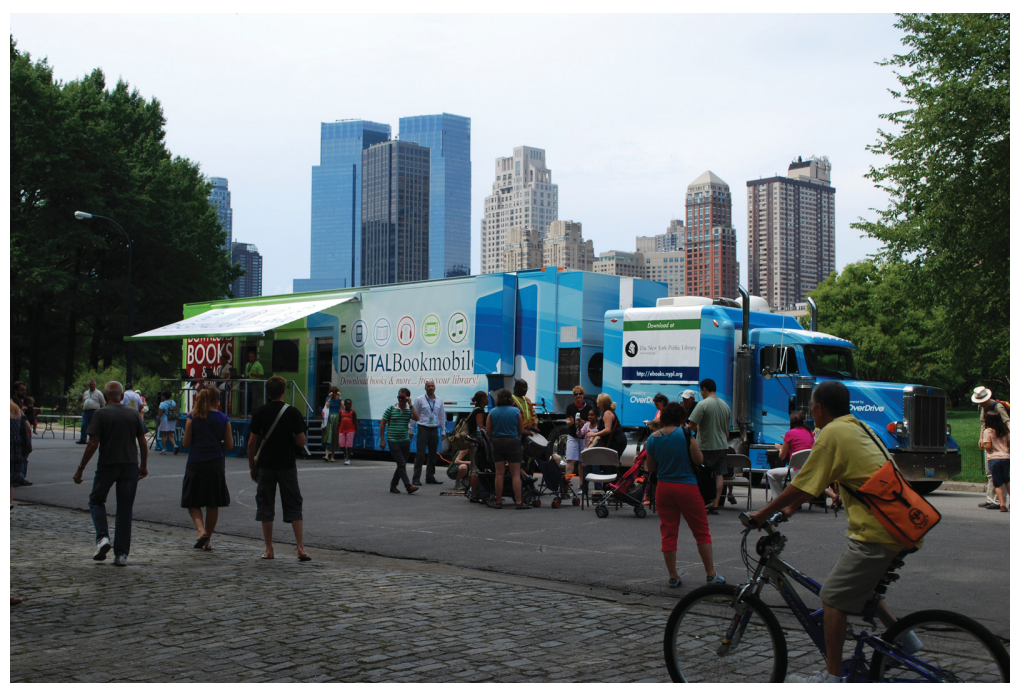

Figure 5 - Urban mobile library

Source: ELEVENTH STACK, 2009.

municipalities of Cali and Bogotá, Colombia, where small, mobile police units, crime scene investigation facilities, and professional cohorts (Figure 4) have been installed to provide surveillance, legal procedures, and assistance in the resolution of everyday conflicts (MARC; WILLMAN, 2010). The mobility of such facilities has enabled them to provide services to wider areas of informal settlements, thus addressing both direct and structural forms of violence experienced by these communities. Additionally, programming denouncing family and intimate partner violence challenged intrinsic 


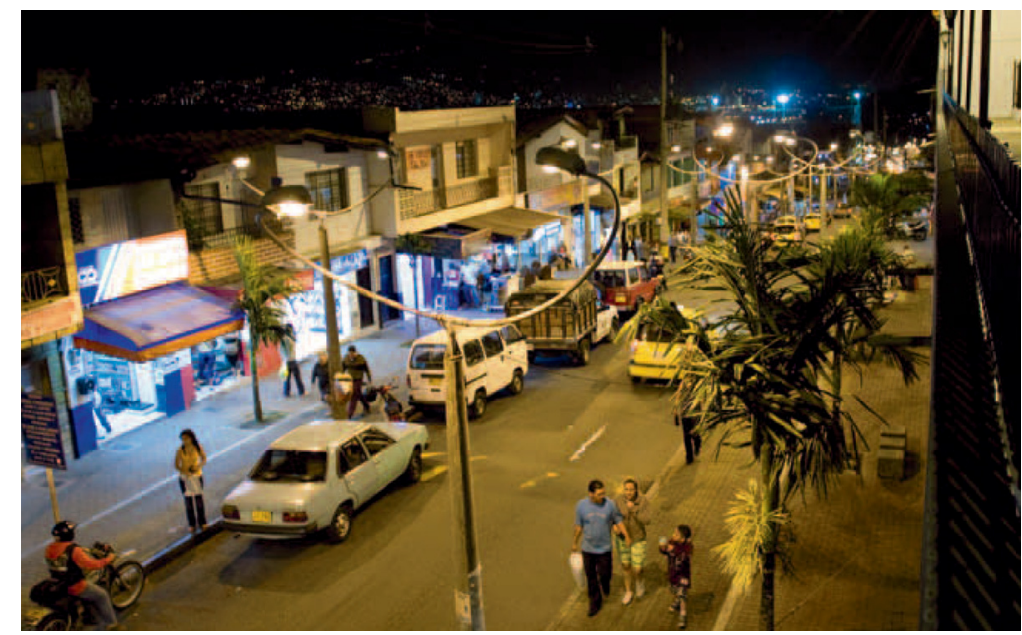

Figure 6 - Enhanced public life in Medellín, Colombia

Source: UNITED NATIONS HUMAN SETTLEMENTS PROGRAMME, 2011.

expressions of cultural violence and likewise achieved relative success (MARC; WILLMAN, 2010, p. 92).

In a similar vein, institutions such as clinics, libraries, or post offices could be established through analogous spatial interventions to attend to the significant absence of such institutions in the barrios. Mobile facilities would address experiences of structural violence in informal communities. Furthermore, this intervention could also foster the communal appropriation of space because these institutions are often locations for congregation (Figure 5). The focus within such intervention is on encouraging an enhanced sense of territoriality (belonging to place) by residents while simultaneously increasing natural surveillance of streets and other public spaces. As the public realm in the barrios has become increasingly unused, the occurrence of violence has become more consistent. Therefore, enhanced surveillance and ownership could foster greater activity in public spaces and promote perceptions of communal safety.

\section{Encouraging business establishment through legal and financial measures}

A comparable spatial mechanism through which activity has been encouraged in the public realm is the development of mixed commercial and residential corridors, particularly in areas of the city at risk for crime. These corridors facilitate pedestrian activity and enhance safety by increasing passive surveillance (Figure 6). Moreover, mixed-use corridors provide viable opportunities for capital generation in crimeprone areas; thus, they diminish the experience of structural violence in communities excluded from the economic development of the formal economy. Such intervention likewise minimizes the need to resort to economic violence for financial gain.

Because barrio streets that have a commercial function are often particularly limited, the development of mixed-use corridors is appropriate to prevent violence in informal communities of the Venezuelan capital (ALEMÁN, 2008). However, additional measures should be developed to more specifically address the situation of violence, particular to Caracas. Legal and financial measures should encourage single mothers to establish businesses through this type of intervention, as extreme poverty tends to concentrate in femaleheaded households across the barrios, reiterating the structural violence inflicted on informal communities (ALEMÁN, 2008). In combination with other municipal deficiencies, the structural violence experienced by youth in these households has a strong tendency to result in acts of social or economic violence across the larger community (CORREO DEL ORINOCO, 2013).

Therefore, facilitating the development of mixed-use corridors enhances violence prevention capabilities on various levels. Greater economic capacity of single mothers would enable them to challenge the forms of structural violence that 
have kept their families in poverty. Moreover, the opportunity to work from home would allow single mothers to attend to their children while engaging in economic activity. This is particularly important because a damaged relationship with the mother figure is a common characteristic of perpetrators of violence in Caracas (CORREO DEL ORINOCO, 2013).

On the communal level, organizations run and managed by women "[...] are felt to be more successful in building sustainable social relations that, in turn, were thought to help prevent the incidence and spread of everyday violence [...]" (MCILWAINE; MOSER, 2007, p. 135). The jobs and local markets created by such interventions could likewise reduce insecurity because they would increase pedestrian activities in the barrios and enhance passive surveillance. Moreover, job development and local markets would address the structural violence that has kept many adults unemployed since the capital reduced its percentage of industrial production in the 1980s. Therefore, legal and financial measures to encourage mixed-used development can help foment a virtuous circle of violence prevention and promote spaces of security within informal communities.

\section{Promoting adolescent-developed \& managed public spaces}

Spatial intervention must also incorporate violence prevention for adolescents as this cohort is over-represented in the figures on violence. Eighty percent of victims and $70 \%$ of homicide perpetrators are males between the ages of 15 and 44 years (GOBIERNO BOLIVARIANO DE VENEZUELAM, 2012), although the majority of both victims and perpetrators are under 25 years (UNIVERSIDAD
NACIONAL EXPERIMENTAL DE LA SEGURIDAD, 2011). Much of this situation can be attributed to the municipal and spatial deficiencies that characterize the barrios. In the parish of Catia in the city's west, for example, $45 \%$ of adolescents between the ages of 16-25 years are not enrolled in secondary education due to deficient facilities (UNIVERSIDAD NACIONAL EXPERIMENTAL DE LA SEGURIDAD, 2011). Moreover, $95 \%$ of adolescents between 19-25 years in the parish do not participate in sports or other organized recreational activities due to a lack of provisions (UNIVERSIDAD NACIONAL EXPERIMENTAL DE LA SEGURIDAD, 2011). Responses to such forms of structural violence often include acts of social or economic violence, which affect the larger community.

Accordingly, spatial intervention should focus on enhancing the accessibility of recreational facilities since exposure to such facilities offers the opportunity to form social norms while providing verbal skills that enable individuals to "[...] express feelings and manage conflicts through negotiation and agreement [...]" (BRICEÑO-LEÓN, 2005, p. 1643). Precedent for such facilities can be drawn from existing programs, including the initiative Labrotorio de Artes Urbano (Tiuna El Fuerte) in Caracas, which provides a space in which the values of creativity, expression, and respect are encouraged in young urban inhabitants (Figure 7) (LABROTORIO DE ARTES URBANO, 2013). Through programs including instruction on graffiti artwork, music, radio broadcasting, and dance as well as other artistic media, Tiuna El Fuerte has been able to reach a substantial portion of local adolescents who do not attend school or participate in athletic or cultural activities. Furthermore, Tiuna El Fuerte programs encourage youth to amend the spaces of the facility to represent the culture of their

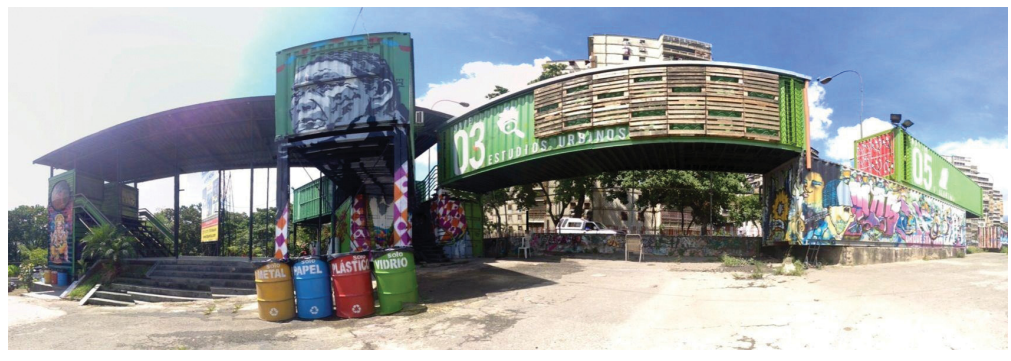

Figure 7 - Labrotorio de Artes Urbano, El Valle, Caracas

Source: BUENADICCION, 2013. 
individual neighborhoods. This ability contributes to the development of self-esteem in participants and discourages the need for detrimental social support or "rituals of masculinity" that often result in social violence (UNIVERSIDAD NACIONAL EXPERIMENTAL DE LA SEGURIDAD, 2011).

Advancing this idea to other public spaces of the barrios provides the potential to prevent insecurity. Adolescent-developed and managed public spaces can reduce direct violence by engaging the youth, who are predominantly associated with violence, in activities for the conception, implementation, control, and management of the public realm. Affording adolescents decision-making capacity can also encourage greater safety because it reduces their experiences of structural violence and could likewise assist them in building relationships with public authorities and services, which might help to prevent acts of violence in the future. Furthermore, spaces designed and managed by adolescents are likely to facilitate greater use of the public realm by this cohort. As previously noted, enhanced public activity would facilitate greater surveillance and could promote a process of ownership of open space.

\section{Fostering the planning capacity of local communities}

In a comparable manner, fostering the planning capacity of local barrio communities can also enhance violence prevention. Programs that delegate greater responsibility for management, assessment, and decision making regarding daily urban conditions in specific localities strengthen the bonds of cooperative autonomy (DAVIS, 2012). Furthermore, the ability to provide care and management for shared community infrastructure "[...] can go a long way in keeping sustained connections within and between citizens and governing authorities [...]" (DAVIS, 2012, p. 19). These connections link the state and citizens to each other in ways that allow increased community autonomy from the agents of violence and promote the realization of focused practices that directly address the origins of insecurity (DAVIS, 2012).

To facilitate greater planning capacity, barrio communities could be afforded financial and professional assistance to realize collectively developed spatial intervention. This capacity to determine the amenities of local spaces affords communities the flexibility to evolve in accordance with changes in the urban environment while similarly encouraging local accountability (UNITED NATIONS HUMAN SETTLEMENTS PROGRAMME, 2012). Moreover, enhanced decision-making capabilities would directly address structural violence, which has excluded the barrios from other processes of urban development. Empowering local communities could likewise contribute to diminishing the deep-seated culture of patronage in the Venezuelan capital that has promoted a form of political violence between conflicting political ideologies (ALEMÁN, 2008).

An opportunity for local planning could focus on expansion or alteration of the built environment as "[...] current rates of population growth suggest that another 100,000 [housing] units will be needed every year $[. .$.$] " to satisfy the contemporary$ deficiency (BRILLEMBOURG; FEIREISS; KLUMPNER, 2005, p. 253).

At the current rate of construction, the authorities undertaking these projects would need 75 years to meet demand; moreover, the various housing solutions attempted thus far are too expensive, inappropriate, and applied without consultation or coordination with the local community. (BRILLEMBOURG; FEIREISS; KLUMPNER, 2005, p. 253).

Therefore, communal planning capacity could augment processes of densification through, for example, locally determined yet municipally advised community zoning ordinances. Such legislation could accommodate the reality of continued barrio development while reducing vulnerability due to poor self-construction. Precedent can be derived from the program Campamentos de Pioneros, which provided a platform for citizens who lost their houses during the mudslides of 2005 to plan and build their own communities with professional assistance (KÜHN, 2013). The structures incorporated to assist in the building process could be applied for similar community construction initiatives in existing settlements. 


\section{Conclusions}

Although the preceding study of Caracas predominantly focused on the contemporary situation of violence in the Venezuelan capital, the rate at which the world is rapidly urbanizing and concentrating populations in insecure and impoverished sections of cities reinforces the value of urban violence research. As metropolitan populations across Latin America, Sub-Saharan Africa, and South and Central Asia continue to grow, the increasing number of individuals exposed to limited resources, competition for employment, dense settlement patterns, and the occurrence of crime has the propensity to exacerbate the incidence of violence. Therefore, mechanisms for the prevention of urban insecurity - particularly in currently violent and urbanizing regions such as Latin America - will be increasingly relevant over the coming decades.

The employment of spatial intervention into prevention mechanisms is desirable in this context as the redevelopment of the built environment affords the capacity to comprehensively address many of the multi-level influences of violence and crime. Amendment of the public realm is furthermore a mechanism through which governments can engage with the communities in which violence concentrates. This is important because it affords the capacity to prevent occurrences of direct violence. It also facilitates government engagement in areas where it has been largely absent, which is fundamental in addressing the deeper structural or cultural experiences of violence that are often characteristic of violent and dangerous communities.

Given this potential, national, federal, and municipal actors engaged in the Gran Mision would do well to optimize spatial intervention in Caracas. Protests from the spring of 2014 have demonstrated that citizens across the country are exasperated by the omnipresence of violence in Venezuela. Yet these protests, which have concentrated in Caracas, also exemplify social, political, and economic differences as well as the fragmentation of the capital city "[...] along various self-centered spatial identities within an interrelated whole [...]" (ALEMÁN, 2008, p. 151).

Therefore, violence prevention must address many of the intrinsic discrepancies within Venezuelan society to prevent insecurity over the long term. Although it is acknowledged that spatial intervention cannot stop violence on its own, redevelopment of the built environment provides the capacity to address many of these differences. The ideals of openness, indeterminacy, fluidity, coexistence, and unassimilated difference "[...] moreover, have found some of their best expressions in the public spaces of modern cities [...]" (CALDEIRA, 2000, p. 303).

\section{References}

ADAMS, T. M. Chronic Violence and its Reproduction: Perverse Trends in Social Relations, Citizenship, and Democracy in Latin America. Washington: Woodrow Wilson Update on the Americas, 2012. Available at: <http://www. wilsoncenter.org/ChronicViolence>. Accessed in: Oct. 2013.

AGBOLA, T. The Architecture of Fear - Urban Design and Construction Response to Urban Violence in Lagos, Nigeria. Ibadan: IFRA; ABB, 1997.

AGOSTINI, G. et al. Understanding the Processes of Urban Violence: An Analytical Framework. Crisis States Research Centre, 2010. Available at: <http://www.eisf. eu/resources/item/?d=4176>. Accessed in: Apr. 2013.

ALEMÁN, A. A. Urban Upgrading Intervention and Barrio Integration in Caracas, Venezuela. 2008. $243 \mathrm{f}$. Thesis (Doctorate in Spatial Planning)-Dortmund University of Technology, Faculty of Spatial Planning, Dortmund, 2008.

AZZELLINI, D.; LANZ, S.; WILDNER, K. Caracas: Urbane Kämpfe und Debatten in der in/formellen Stadt. In: AZZELLINI, D.; LANZ, S.; WILDNER, K. Caracas, Sozialisierende Stadt - Die "bolivarianische" Metropole zwischen Selbstorganisation und Steuerung. Berlin: b_books, 2013. vol. 12. MetroZones, p. 7-22.

BRICEÑO-LEÓN, R;; ZUBILLAGA, V. Violence and Globalization in Latin America. Current Sociology, v. 50, n. 1, p. 19-37, 2002. http://dx.doi.org/10.1177/0011392102050001003

BRICEÑO-LEÓN, R. Urban Violence and Public Health in Latin America: A Sociological Explanatory Framework. Cadernos de Saúde Pública, v. 21, n. 6, p. 1629-1648, 2005. PMid:16410839. http://dx.doi.org/10.1590/ S0102-311X2005000600002

BRICEÑO-LEÓN, R. Caracas. In: KOONINGS, K.; KRUIJT, D. (Eds.): Fractured Cities: Social Exclusion, Urban Violence 
and Contested Spaces in Latin America. London: Zed Books; New York: Palgrave Macmillan, 2007. p. 86-100. BRICEÑO-LEÓN, R.; CAMARDIEL, A.; AVILA, O. Attitudes Toward the Right to Kill in Latin American Culture. Journal of Contemporary Criminal Justice, v. 22, n. 4, p. 303323, 2006. http://dx.doi.org/10.1177/1043986206297092

BRILLEMBOURG, A.; FEIREISS, K.; KLUMPNER, H. (Eds.). Informal City: Caracas Case. Munich; London: Prestel, 2005.

BRILLEMBOURG, A.; KLUMPNER, H.; SCHWARTZ, D. Build Simply: South of the Border. Mas Context Conflict, n. 10, p. 14-28, summer 2011.

BUENADICCION. Labrotorio de Artes Urbano de Caracas Gana Premio Internacional. BuenaDiccion. Caracas, 2013. Available at: <http://buenadiccion.com/mostrar. php?bdparam=laboratorio_de_arte_urbano_de_caracas_ gana_premio_internacional>. Accessed in: Mar. 2013.

CALDEIRA, T. P. City of Walls: Crime, Segregation, and Citizenship in São Paulo. Berkely: University of California Press, 2000.

CENTENARIO DE VILLANUEVA. Sitio Web Centenario de Carlos Raúl Villanueva. Universidad Central de Venezuela. 2011. Available at: <http://www.centenariovillanueva. web.ve/>. Accessed in: 20 Dec. 2013.

CORREO DEL ORINOCO. El Padre Alejandro Moreno asegura que no se ha hecho lo suficiente para el desarme. Caracas, 2013. Available at: <http:// comisionpresidencialdesarme.gob.ve/index.php/ entrevistas/item/480-el-padre-alejandro-morenoasegura-que-no-se-ha-hecho-lo-suficiente-para-eldesarme>. Accessed in: July 2013.

DAVIS, D. E. A Toolkit for Urban Resilience in Situations of Chronic Violence. Massachusetts, 2012. Available at: $<$ http://web.mit.edu/cis/urban_resilience.html $>$. Accessed in: May 2013.

DÍAZ, F. J.; MELLER, P. (Ed.). Violencia y Cohesión Social en América Latina. Santiago: Uqbar Editores, 2012.

ELEVENTH STACK. What's a Digital Bookmobile. 2009. Available at: <http://eleventhstack.wordpress. com/2009/09/30/whats-a-digital-bookmobile/>. Accessed in: Feb. 2014.

ELJURI, E. et al. Encuesta Nacional de Victimización y Percepción de Seguridad Ciudadana 2009 (ENVPSC-2009): Documento Técnico. Caracas: Republica Bolivariana de Venezuela, 2010.
FAJNZYLBER, P.; LEDERMAN, D.; LOAYZA, N. What Causes Violent Crime? European Economic Review, v. 46, p. 1323-1357, 2002. http://dx.doi.org/10.1016/ S0014-2921(01)00096-4

FISCHER, D. Peace as a Self-Regulating Process. In: WEBEL, C.; GALTUNG, J. (Ed.). Handbook of Peace and Conflict Studies. London; New York: Routledge, 2007. p. 187-205. PMid:17325749. http://dx.doi.org/ 10.4324/9780203089163.ch13

FRIEDMANN, J. Venezuela: From Doctrine to Dialogue. Syracuse: Syracuse University Press, 1965. PMCid: PMC472992.

GALTUNG, J. Violence, Peace, and Peace Research. Journal of Peace Research, v. 6, n. 3, p. 167-191, 1969. http:// dx.doi.org/10.1177/002234336900600301

GOBIERNO BOLIVARIANO DE VENEZUELA. Gran Misión A Toda Vida Venezuela: Por una Convivencia Segura. 2012. Available at: <http://conciencia.mcti.gob.ve/assets/ publico/enlaces/ pdf/relevantes/mision.pdf $>$. Accessed in: Jan. 2012.

GRATIUS, S.; VALENÇA, M. Urban Violence in Caracas and Rio de Janeiro: Local and European Responses. 2011. Available at: <http://www.ifp-ew.eu>. Accessed in: Feb. 2013.

HOLSTON, J. Insurgent Citizenship in an Era of Global Urban Peripheries. Urban Peripheries. Centre of Contemporary Culture of Barcelona, Barcelona. 13 Dec. 2007. Public Space. Web. 16 Feb. 20114. <http://www.public space.org/es/texto-biblioteca/eng/b001-insurgent-citizen ship-in-an-era-of-global-urban-peripheries> .

JÁCOME, F.; GRATIUS, S. Violencia, Inseguridad, y Polarización Política en Venezuela. 2011. Available at: $<$ http://www.ifp-ew.eu/pdf/201111IfPEWFRIDEViolencia InseguridadEn Venezuela.pdf>. Accessed in: Feb. 2013.

KRAUSE, M. Violence Prevention through Urban Upgrading in the Township of Khayelitsha, Cape Town, South Africa. TRIALOG Journal for Planning and Building in the Third World, v. 108, p. 26-35, 2011.

KRUG, E.; DAHLBERG, L.; MERCY, J. A. World report on Violence \& Health. Summary. WHO, 2002. Available at: <http://www.who.int/violence_injury_prevention/ violence/world_report/en/>. Accessed in: Apr. 2013.

KÜHN, J. Landreform und urbane Kämpfe in Caracas. In: AZZELLINI, D.; LANZ, S.; WILDNER, K. Caracas, Sozialisierende Stadt - Die "bolivarianische" Metropole 
zwischen Selbstorganisation und Steuerung. Berlin: b_books, 2013. (MetroZones, v. 12). p. 190-209.

LABROTORIO DE ARTES URBANO - LAU. Micro Info LAU - Subtitulado. 2013. [Movie]. Available at: <https:// www.youtube.com/watch?v=cA_DIbMP7Vs>. Accessed in: Apr. 2013.

MARC, A.; WILLMAN, A. M. Violence in the City: Understanding and Supporting Community Responses to Urban Violence. Washington: World Bank, 2010.

MAYTÍN, M. Drei historische Momente in der städtischen Entwicklung von Caracas. In: AZZELLINI, D.; LANZ, S.; WILDNER, K. Caracas, Sozialisierende Stadt - Die "bolivarianische" Metropole zwischen Selbstorganisation und Steuerung. Berlin: b_books, 2013. vol. 12. MetroZones, p. 58-73.

MCILWAINE, C.; MOSER, C. O. N. Living in Fear: How the Urban Poor Perceive Violence, Fear, and Insecurity. In: KOONING, K.; FRUIJT, D. (Ed.). Fractured Cities: Social Exclusion, Urban Violence and Contested Spaces in Latin America. London: Zed Books; New York: Palgrave Macmillan, 2007. p. 117-137.

MOSER, C. O. N. Urban Violence and Insecurity. An Introductory Roadmap. Environment and Urbanization, v. 16, n. 2, p. 3-16, 2004. http://dx.doi.org/10.1177/ 095624780401600220

MOSER, C. O. N.; MCILWAINE, C. Encounters with Daily Violence in Latin America: Urban poor perceptions from Columbia and Guatemala. New York: Routledge, 2004.

MUGGAH, R. Researching the Urban Dilemma: Urbanization, Poverty and Violence. 2012. Available at: <http://www.idrc.ca/EN/Programs/Social_and_ Economic_Policy/Governance_Security_and_Justice/Pages/ ArticleDetails.aspx?PublicationID=1096>. Accessed in: Mar. 2013.

RAY, T. F. The Politics of the Barrios of Venezuela. Berkeley: University of California Press, 1969.

SALIEZ, F. et al. The State of Latin American and Caribbean Cities 2012: Towards a new urban transition. Naples: UNHABITAT, 2012.

SÁNCHEZ, S. Die Umsiedlung der informellen Wirtschaft in der Stadt Caracas. In: AZZELLINI, D.; LANZ, S.; WILDNER, K. Caracas, Sozialisierende Stadt - Die "bolivarianische" Metropole zwischen Selbstorganisation und Steuerung. Berlin: b_books, 2013. (MetroZones, v. 12). p. 111-19.
SANJUÁN, A. M. Dimensionamiento y Caracterización de las Violencias en Caracas. El Slavador: Inter-American Development Bank, 1998.

SANJUÁN, A. M. Democracy, Citizenship, and Violence in Venezuela. In: ROTKER, S.; GOLDMAN, K. (Ed.). Citizens of Fear: Urban Violence in Latin America. New Brunswick: Rutgers University Press, 2002. p. 87-101.

SANTA-BARBARA, J. Peace Business: An Introduction. In: WEBEL, C.; GALTUNG, J. (Ed.). Handbook of Peace and Conflict Studies. London; New York: Routledge, 2007. p. 232-247. http://dx.doi.org/10.4324/9780203089163. $\operatorname{ch} 15$

STANN, E. Caracas Venezuela, 1891-1936. 1975. Thesis (Doctorate of Philosophy)-Vanderbilt University, Vanderbilt, 1975.

THE ECONOMIST INTELLIGENCE UNIT LIMITED. Worldwide Cost of Living 2013: Which City is the Most Expensive to Live In? London, 2013. Available at: <https://www.eiu.com/public/topical_report. aspx?campaignid=WCol2013>. Accessed in: May 2013.

UNITED NATIONS HUMAN SETTLEMENTS PROGRAMME - UN-HABITAT. Urban Planning for City Leaders. Nairobi: UN-HABITAT, 2012.

UNITED NATIONS HUMAN SETTLEMENTS PROGRAMME - UN-HABITAT. Building Urban Safety through Slum Upgrading. Nairobi: UN-HABITAT, 2011.

UNIVERSIDAD NACIONAL EXPERIMENTAL DE LA SEGURIDAD - UNES. Violencia Juventil y Construccion de Identidades. Caracas: UNES, 2011. Available at: <http://www.unes.edu.ve/index.php?option=com_content \&view=article\&id=3980>. Accessed in: June 2013.

VANDERSCHUEREN, F. From Violence to Justice and Security in Cities. Environment and Urbanization, v. 8, n. 1, p. 93-112, 1996. http://dx.doi.org/ $10.1177 / 095624789600800119$

ZUBILlAGA, V. Menos Desigualdad, más Violencia: la Paradoja de Caracas. Nueva Sociedad, n. 243, p. 104118, Ene./Feb. 2013.

Recebido: 03/01/2014

Received: 01/03/2014

Aprovado: 27/03/2014

Approved: 03/27/2014 